\title{
Haemophilus somnus - Unlikely to be a Causative Microbiological Agent in Bovine Clinical Mastitis in Denmark
}

Haemophilus somnus is a Gram-negative bacterium, which is the cause of a clinical syndrome in cattle that may include pneumonia, myocardial abscessation, arthritis, thrombotic meningoencephalitis, genital infections and mastitis (Humphrey \& Stephens 1983, Armstrong et al. 1986, Higgins et al. 1987, Harris \& Janzen 1989, Kwiecien \& Little 1992). In Denmark the infection is mainly found in the respiratory tract of calves (Krogh et al. 1986, Wedderkopp 1991).

H. somnus is wide-spread in the cattle population, but growth of the bacteria on agar plates presupposes an atmosphere containing a minimum of $5 \% \mathrm{CO}_{2}$ (Merino \& Biberstein 1982), a technique which is not used routinely in laboratory examinations of mastitis cases. In a traditional microbiological study of cases of clinical bovine mastitis, no growth of any microbiological agents was seen in $11.8 \%$ of the samples (Aalbcek et al. 1994). The present study was undertaken in order to investigate whether $\mathrm{H}$. somnus can be involved in cases of bovine mastitis.

Bovine mammary secretions from 6809 quarters, representing 3783 cows suffering from clinical mastitis were carefully examined. The samples were collected from May 1994 to April 1995, and the milk samples had been submitted to the laboratory by veterinary practitioners for bacteriological examination. The samples re- present herds from all parts of Denmark. In this study no control group was included, like cases of subclinical mastitis. Also, the disease history was often scarce leaving the laboratory uninformed about the severity of the cases.

For routine examination drops of milk were spread on esculin blood ager without and with $0.1 \mathrm{IU}$ penicillin. The plates were incubated overnight at $37^{\circ} \mathrm{C}$ in a "candle jar", which approximately generates an atmosphere containing $2.5 \% \mathrm{CO}_{2}$. Parallel to the routine examinations another plate without penicillin was incubated for $20 \mathrm{~h}$ at $37^{\circ} \mathrm{C}$ in an atmosphere containing $5 \% \mathrm{CO}_{2}$.

Esculin agar, used for routine examinations of mastitis cases in Denmark, consists of peptone (Difco) $11.66 \mathrm{~g}$, agar $12.0 \mathrm{~g}$, meat extract (Fleischextrakt rocken, Merck) $4.0 \mathrm{~g}$, $\mathrm{Na}_{2} \mathrm{HPO}_{4}, 2 \mathrm{H}_{2} \mathrm{O} 1.5 \mathrm{~g}, \mathrm{NaCl} 5.0 \mathrm{~g}$, yeast extract (Difco) $3.0 \mathrm{~g}$, esculin (Merck) $1.0 \mathrm{~g}$, tryptone (Difco) $8.3 \mathrm{~g}$, glucose (Merck) $0.44 \mathrm{~g}$, distilled water $1000 \mathrm{ml}(\mathrm{pH} \mathrm{7.4)}$, and $5 \%$ sterile bovine stabilized blood.

At the routine examination bacteriological growth was seen in 4266 of the cases, in 430 of the cases it was possible to demonstrate 2 different pathogens in secretions from one milk quarter. The bacteriological diagnoses are shown in Table 1. In the group "other pathogens" only a few bacteria from different species were found, such as various types of haemolytic Streptococcus, Klebsiella, Listeria mono- 
Table 1. Bacteriological diagnosis after routine examination of mammary secretions from 6809 milk quarters in 3783 individual cows suffering from clinical mastitis. In the group "Other pathogens" only a few bacteria representing different species were found.

\begin{tabular}{lrr}
\hline Diagnosis & Number & Per cent \\
\hline Strepcococcus dysgalactia & 827 & 11.4 \\
Streptococcus uberis & 685 & 9.5 \\
Staphyloccus aureus & 1067 & 14.7 \\
Coagulase negative staphylococci and micrococci & 456 & 6.3 \\
Penicillin resistent Staphylococcus aureus & 217 & 3.0 \\
Actinomyces pyogenes & 195 & 2.7 \\
Yeast cells & 96 & 1.3 \\
Coliform group & 727 & 10.0 \\
Faecal streptococci & 137 & 1.9 \\
Contaminated samples & 179 & 2.6 \\
No pathogen found & 2543 & 35.1 \\
Other pathogens & 110 & 1.5 \\
\hline Total & 7239 & 100.0 \\
\hline
\end{tabular}

cytogenes, Pasteurella multocida, Proteus and Pseudomonas.

Due to no growth of any microbiological agent, drops from 2543 of the samples were spread on esculin blood agar for a second time and incubated at $37^{\circ} \mathrm{C}$ in an atmosphere containing $5 \%$ $\mathrm{CO}_{2}$. All the plates were read twice, after $20 \mathrm{~h}$ and after $44 \mathrm{~h}$.

H. somnus was isolated in only one case and in pure culture from a cow showing a rather mild clinical mastitis.

In this study the growth conditions for $\mathrm{H}$. somnus on agar plates were optimal. Prior to this study isolation of $\mathrm{H}$. somnus has only been reported twice in connection with acute bovine mastitis in Denmark (Wedderkopp \& Nylin 1994). Experimentally $H$. somnus is capable of producing either a chronic form or a severe gangrenous form of bovine mastitis (Hazlett et al. 1983). Two cases of severe clinical mastitis in dairy cows, where $H$. somnus was isolated in pure culture, have been reported from Canada (Armstrong et al. 1986, Harris \& Janzen 1989). The fact that only one isolate of $H$. somnus was demonstrated in this material indicates that $H$. somnus cannot be a major cause of bovine clinical mastitis in Denmark.

At the Cattle Health Laboratory, the $\mathrm{CO}_{2}$-incubator is now being used instead of the "candle jar" for routine examination of milk samples from cows suffering from clinical mastitis.

\section{A. Wedderkopp}

Cattle Health Laboratory, Danish Dairy Board, Brørup, Denmark.

\section{References}

Aalbaek B, Stenderup J, Jensen HE, Valbak J, Nylin B, Huda A: Mycotic and algal bovine mastitis in Denmark. APMIS 1994, 102, 451-456.

Armstrong KR, Osborne AD, Janzen ED: Haemophilus somnus Mastitis in a Dairy Cow. Can.Vet.J. 1986, 27, 211-212.

Harris FW, Janzen ED: Haemophilus somnus disease complex (hemophilosis): A review. Can.Vet.J. 1989, 30, 816-822.

Hazlett MJ, Little PB, Barnum DA: Experimental Production of Mastitis with Haemophilus somnus in the Lactating Bovine Mammary Gland. Can.Vet.J. 1983, 24, 135-136.

Higgins R, Martin JR, Laurouche Y, Coyette G: Mastitis caused by Haemophilus somnus in a dairy cow. Can.Vet.J. 1987, 28, 117-119. 
Humphrey JP, Stephens LR: Haemophilus somnus: A Review. Vet Bull 1983, 53, 987-1004.

Krogh $H V$, Pedersen KB, Friis $N F$ : Pneumonia in calves associated with Haemophilus somnus. 14. World Congres on Diseases of Cattle. Dublin 1986: 585-589.

Kwiecien JM, Little PB: Isolation of pathogenic strains of Haemophilus somnus form the female bovine reproductive tract. Can.J.Vet.Res. 1992, $56,127-134$.
Merino M, Biberstein EL: Growth requirements of Haemophilus somnus. J.Clin.Microbiol. 1982, 16, 798-803.

Wedderkopp A: Report on Haemophilus somnus in calves. Danish Veterinary Laboratory 1991, 32 pp.

Wedderkopp A, Nylin B: Haemophilus somnus isoleret fra tilfælde af akut klinisk mastitis. $(\mathrm{H}$. somnus isolated from a case of acute bovine mastitis) Dansk Veterinærtidsskrift 1994, 77, 935.

(Received November 26, 1996; accepted February 5. 1997).

Reprints may be obtained form: A. Wedderkopp, Cattle Health Laboratory, Danish Dairy Board, Ladelundvej 85A, DK-6650 Brørup, Denmark. E-mail: lab@mejeri.dk, tel: + 4576600 600, fax: + 4576600601. 
